Review

\title{
Influence of metal nuclearity and physicochemical properties of ceria on the oxidation of carbon monoxide
}

\author{
Linxi Wang a, Shyam Deo a, Kerry Dooley c, Michael J. Janik a,*, Robert M. Rioux a,b,\# \\ a Department of Chemical Engineering, The Pennsylvania State University, University Park, PA 16801 USA \\ b Department of Chemistry, The Pennsylvania State University, University Park, PA 16801 USA \\ c Department of Chemical Engineering, Louisiana State University, Baton Rouge, LA 70803 USA
}

\section{A R T I C L E I N F}

\section{Article history:}

Received 5 November 2019

Accepted 2 December 2019

Published 5 June 2020

\section{Keywords:}

Ceria

CO oxidation

Metal nanoparticles

Single atoms

Preferential oxidation of CO

Metal nuclearity

\begin{abstract}
A B S T R A C T
The redox properties of ceria make it suitable as a catalyst or support in oxidation reactions. Ceria-supported transition metal nanoparticles or isolated single atoms provide a metal-support interface that reduces the energy cost to remove interfacial oxygen atoms, providing active oxygen species that can participate in Mars van Krevelen oxidation processes. CO oxidation is a key probe reaction to test the reducibility of ceria-supported catalysts and is also practically important in the elimination of $\mathrm{CO}$ at relatively low temperatures in various applications. Preferential oxidation of $\mathrm{CO}$ (PROX) in excess $\mathrm{H}_{2}$ controls the $\mathrm{CO}$ concentration to ultra-low levels to prevent poisoning of hydrogen oxidation electrocatalysts. The reactivity of catalysts in $\mathrm{CO}$ oxidation and selectivity towards $\mathrm{CO}$ over $\mathrm{H}_{2}$ in PROX is dependent on the type and dispersion of metal species, the structural and chemical properties of $\mathrm{CeO}_{2}$, and the synthetic preparation methods of the catalysts. In this review, we summarize recently published works on catalytic CO oxidation and PROX reactions on ceria-supported metal nanoparticles and single atoms. We summarize the reactivity on different supported metals, and on different $\mathrm{CeO}_{2}$ surfaces with the same metal. We summarize the most likely reaction mechanisms as suggested by density functional theory calculations. The factors contributing to selectivity towards CO oxidation in PROX reactions on various supported metals are also discussed.
\end{abstract}

(C) 2020, Dalian Institute of Chemical Physics, Chinese Academy of Sciences. Published by Elsevier B.V. All rights reserved.

\section{Introduction}

$\mathrm{CeO}_{2}$ is a versatile catalytic material which has generated considerable interest in both academia and industry. Since $\mathrm{CeO}_{2}$ was first employed by the Ford Motor Company as an oxygen storage component in car converters in 1976, the inclusion of $\mathrm{CeO}_{2}$ as a key component in three-way catalysts (TWCs) has escalated dramatically in the automobile industry [1]. Beyond commercial applications, ceria-based catalysis has been extensively studied for numerous reactions, including $\mathrm{CO}$ oxidation, preferential oxidation of $\mathrm{CO}$ (PROX) over $\mathrm{H}_{2}$, water-gas shift (WGS), methane combustion, selective hydrogenations, oxidation of light organic compounds, and $\mathrm{C}-\mathrm{C}$ coupling reactions [2-6].

Ceria is a yellow or white powder that crystallizes in the fluorite structure with a Fm3m space group and a face-centered cubic (fcc) unit cell. Cerium has a $4 f^{2} 5 s^{2} 5 p^{6} 6 s^{2}$ electron configuration and exhibits both +3 and +4 oxidation states, leading to

\footnotetext{
* Corresponding author. E-mail: mjj13@psu.edu

\# Corresponding author. E-mail: rmr189@psu.edu

All authors acknowledge funding of this work by the National Science Foundation, Division of Chemical, Bioengineering, Environmental and Transport Systems (CBET) through Award \# 1800507 and 1510435.

DOI: 10.1016/S1872-2067(20)63557-4 | http://www.sciencedirect.com/science/journal/18722067 | Chin. J. Catal., Vol. 41, No. 6, June 2020
} 
the formation of both $\mathrm{Ce}_{2} \mathrm{O}_{3}$ and $\mathrm{CeO}_{2}$ in the presence of oxygen at high temperatures [7]. A variety of metastable intermediate states $\left(\mathrm{CeO}_{2-x}\right)$ of near-fluorite structure exist with oxygen vacancies randomly distributed [8]. The vacancy concentration and distribution depends on temperature and oxygen pressure, endowing $\mathrm{CeO}_{2}$ with reducibility and wide applicability as an oxygen storage material within a multi-component oxidation catalyst [9].

Carbon monoxide ( $\mathrm{CO}$ ) is the product of incomplete combustion of carbon-based fuels. CO emissions must be avoided since the lethal gas binds strongly to hemoglobin, disabling it from delivering oxygen to bodily tissues. Further oxidation of $\mathrm{CO}$ to $\mathrm{CO}_{2}$ is a highly exothermic reaction with a remarkably high ignition temperature at $609^{\circ} \mathrm{C}$.

$$
\mathrm{CO}+1 / 2 \mathrm{O}_{2} \rightarrow \mathrm{CO}_{2} \quad \Delta H=-283 \mathrm{~kJ} / \mathrm{mol}
$$

The oxidation of $\mathrm{CO}$ is a useful probe reaction of the reducibility of $\mathrm{CeO}_{2}$-based catalysts, a key property impacting the activity of catalysts. $\mathrm{CeO}_{2}$ is a good candidate for $\mathrm{CO}$ oxidation at non-UHV pressures due to active surface oxygen (both superoxo and peroxo) that react with the $\mathrm{CO}$ on the surface of ceria. During the oxidation process, CO initially reacts with active surface oxygen to form $\mathrm{CO}_{3}$ [2-8] which then reacts with $\mathrm{O}_{2}$ to yield $\mathrm{CO}_{2}$ and regenerate active surface oxygen. These reactive oxygen intermediates arise from the $\mathrm{Ce}^{4+}-\mathrm{Ce}^{3+}$ redox couple, and their formation is dependent on the ease of oxygen vacancy formation [10]. Atmospheric oxygen does not directly adsorb and dissociate at the vacant sites, but the redox process involving the formation and replenishing of oxygen vacancies on $\mathrm{CeO}_{2}$ is described as a Mars van Krevelen (MvK) mechanism [11].

PROX over $\mathrm{H}_{2}$ is an important reaction in proton-exchange membrane fuel cells (PEMFC), which exploit hydrogen as an energy source. The concentration of $\mathrm{CO}$ in the feed must be kept at an ultra-low level $(<50 \mathrm{ppm})$ to prevent poisoning of the hydrogen oxidation electrode, typically made from noble metals $[12,13]$. Thus, elimination of the trace amount of CO from $\mathrm{H}_{2}$ is required. One strategy to reduce the concentration of $\mathrm{CO}$ is via the water-gas shift reaction, where $\mathrm{CO}$ is oxidized by $\mathrm{H}_{2} \mathrm{O}$ to $\mathrm{CO}_{2}$ while producing $\mathrm{H}_{2}$, but this reaction often requires high(er) temperatures than an alternate approach.

$$
\mathrm{CO}+\mathrm{H}_{2} \mathrm{O} \rightarrow \mathrm{CO}_{2}+\mathrm{H}_{2} \quad \Delta H=-41 \mathrm{~kJ} / \mathrm{mol}
$$

The other approach is preferential oxidation using $\mathrm{O}_{2}$ (PROX):

$\mathrm{CO}+1 / 2 \mathrm{O}_{2} \rightarrow \mathrm{CO}_{2} \quad \Delta H=-283 \mathrm{~kJ} / \mathrm{mol}$ desired reaction

$\mathrm{H}_{2}+1 / 2 \mathrm{O}_{2} \rightarrow \mathrm{H}_{2} \mathrm{O} \quad \Delta H=-286 \mathrm{~kJ} / \mathrm{mol}$ undesired reaction

Selective adsorption of $\mathrm{CO}$ and suppression of hydrogen dissociation on the catalyst surface are essential to achieve PROX, which requires prudent selection of supported metals as binding sites because ceria itself is active towards both $\mathrm{CO}$ and hydrogen oxidation $[14,15]$.

The surface properties of ceria can be modified by the deposition of noble metals. Common synthetic methods to deposit metals as nanoparticles on oxide supports include direct metal deposition on the surface of as-synthesized $\mathrm{CeO}_{2}$, or co-precipitation of the metal dopant with $\mathrm{CeO}_{2}$ in a single step. The supported metal forms a strong interaction with the ceria support at their interface, often decreasing the energy penalty for the formation of an oxygen vacancy. Therefore, tuning the interaction between metal and $\mathrm{CeO}_{2}$ is vital to catalytic performance in oxidation reactions.

Ceria-based catalysts are well-studied and reviews on the surface chemistry [8], redox properties [3] and industrial application of bare ceria have been published [2,5]. Ceria-supported metal catalysts and other heterogeneous catalysts have been summarized in a number of reviews where the focus has been on the stability [16], surface chemistry $[17,18]$ and catalysis of ceria-supported metal catalysts [6,19]. In addition, with the strong interest in single-atom catalysis, single atoms supported on ceria have been discussed and compared with other supports for small molecule catalytic chemistries [6,20-22]. Herein, the focus of this review is on topics related to oxidation of $\mathrm{CO}$ on $\mathrm{CeO}_{2}$-supported metal catalysts, with an emphasis on the difference in catalytic performance as an outcome of the different synthetic methods, structural/chemical properties of the ceria support, and choice of supported metal species. The catalyst's performance is mainly demonstrated by its reactivity and selectivity towards $\mathrm{CO}$ (rather than $\mathrm{H}_{2}$ ) oxidation, while the reaction mechanism is either studied by DFT calculations or inferred from kinetic studies and/or experimental characterization of reaction intermediates.

\section{2. $\mathrm{CO}$ oxidation on $\mathrm{CeO}_{2}$-supported nanoparticles}

\subsection{CO oxidation}

Although bulk metallic gold is considered chemically inert, it shows great catalytic activity when deposited on an active $\mathrm{CeO}_{2}$ support and dispersed as nanoparticles [23,24]. Low-temperature performance for $\mathrm{CO}$ oxidation has been widely reported on $\mathrm{Au} / \mathrm{CeO}_{2}$. The activity of these catalysts, however, depends on the preparation method, the properties of the $\mathrm{CeO}_{2}$ support, the size of the $\mathrm{Au}$ nanoparticles and the presence of moisture [24]. For example, Han et al. [25] prepared $\mathrm{Au} / \mathrm{CeO}_{2}$ following two synthetic routes - either via deposition of $\mathrm{HAuCl}_{4}$ on a hydrothermally synthesized ceria support, or via co-precipitation of $\mathrm{HAuCl}_{4}$ and $\mathrm{Ce}\left(\mathrm{NO}_{3}\right)_{3}$. The samples prepared via the first route showed a much higher activity and greater performance at lower temperature [25]. XPS analysis on the most active $\mathrm{Au} / \mathrm{CeO}_{2}$ demonstrated $\mathrm{Au}$ predominantly as $\mathrm{Au}^{+}$, which they proposed as the active species [25]. Guzman et al. [26] applied FTIR with CO as a probe molecule to quantify the concentration of $\mathrm{Au}^{3+}, \mathrm{Au}^{+}$and $\mathrm{Au}^{0}$ on $\mathrm{Au} / \mathrm{CeO}_{2}$ catalysts made by a deposition-precipitation method, and found the specific activity in $\mathrm{CO}$ oxidation (molco $\mathrm{g}_{\mathrm{Au}^{-1}} \mathrm{~h}^{-1}$ ) almost linearly correlated with the concentration of $\mathrm{Au}^{3+}$, while no correlation was found between the activity and the concentration of $\mathrm{Au}^{+}$and $\mathrm{Au}^{0}$. Carrettin et al. [27] found $\mathrm{Au}$ nanoparticles deposited on nanocrystalline $\mathrm{CeO}_{2}$ demonstrated reactivity two orders of magnitude higher than $\mathrm{Au} / \mathrm{CeO}_{2}$ catalysts prepared by coprecipitation or deposition of $\mathrm{Au}$ on bulk $\mathrm{CeO}_{2}$.

Accounting for such differences in the details of the ceria support must consider size effects as it has been shown that although larger $\mathrm{Au}$ NPs can dissociate $\mathrm{O}_{2}$ [28], their lower dis- 
persions lead to lower specific activity. Very small Au clusters, by virtue of a decreased d-band occupancy, adsorb both $\mathrm{CO}$ and $\mathrm{H}_{2}$ very strongly, and so become inactive for $\mathrm{CO}$ oxidation [29]. The zero-valent metal is not active for CO oxidation, even though it is almost always present, especially at PROX conditions [30]. $\mathrm{Au}^{+}$at the $\mathrm{CeO}_{2}$ interface, often formed under reaction conditions from $\mathrm{Au}^{3+}$, is a likely active site for selective $\mathrm{CO}$ oxidation at low temperatures, and these findings are in agreement with those on related catalysts such as $\mathrm{Au} / \mathrm{TiO}_{2}$ and $\mathrm{Au} / \mathrm{Fe}_{2} \mathrm{O}_{3}$ [30].

The effect of humidity in the feed has been studied by Zhang et al. [31], who observed a reduced induction period and enhanced initial activity under humid conditions (Fig. 1 top). In-situ DRIFTS detected the presence of a surface $\mathrm{COOH}$ intermediate under both wet and dry conditions, which formed upon the interaction between adsorbed $\mathrm{CO}$ and surface hydroxyl groups [31]. The authors attributed the shorter induction time under humid conditions to the rapid formation of abundant $\mathrm{COOH}$, since water readily dissociated in the vicinity of gold nanoparticles, whereas there was a limited amount of hydroxyl species available under dry conditions (Fig. 1, bottom) [31].


Fig. 1. (top) $\mathrm{CO}$ conversion versus time on stream over $\mathrm{Au} / \mathrm{CeO}_{2}$ catalysts under humid and dry conditions at $20^{\circ} \mathrm{C}$. (bottom) Schematic diagram of proposed mechanism for the induction period, where the hydroxyl groups migrate to and/or from the gold nanoparticles in (A) dry and (B) humid condition. Reprinted with permission from Ref. [31], copyright 2014, ACS Catalysis.
After the induction period, however, the reaction quickly transited into a fast deactivation phase under humid conditions due to the blockage of active sites by water molecules, while such deactivation was absent under dry conditions (Fig. 1, top) [31]. A subsequent deactivation stage, at a slower rate, was observed in both wet and dry conditions, due to the gradual accumulation of surface carbonate species, as identified by DRIFT measurements, which blocked the active Au sites [31].

Ceria-supported Pd nanoparticles also oxidize CO at ambient temperatures. Tereshchenko et al. [32] reported high catalytic activity on supported $\mathrm{Pd} / \mathrm{CeO}_{2}$ (111) at a loading of $5 \mathrm{wt} \%$ Pd and a dispersion of $50 \%-75 \%(1.5-2 \mathrm{~nm})$, where the CO conversion reached $100 \%$ at $50{ }^{\circ} \mathrm{C}$. Yang et al. [33] prepared $\mathrm{Pd} / \mathrm{CeO}_{2}$ via a laser vaporization at the same $\mathrm{Pd}$ weight loading (5 wt\%) but with larger Pd nanoparticle sizes (5-10 nm), and reported $100 \%$ conversion at $108{ }^{\circ} \mathrm{C}$. The difference in catalytic activity could be attributed to higher Pd dispersion in Tereshchenko's work, and higher activity on the $\mathrm{CeO}_{2}$ (111) nanostructures [32].

The shape-dependent activity of $\mathrm{Pd} / \mathrm{CeO}_{2}$ nanocrystals has been compared by Hu et al. [34], who deposited $1.0 \mathrm{wt} \% \mathrm{Pd}$ on different ceria nanocrystals and found $\mathrm{Pd} / \mathrm{CeO}_{2}$-rods (consisting of primarily (110) and (100) facets) were more reactive with a lower activation energy than $\mathrm{Pd} / \mathrm{CeO}_{2}$-cubes (only (100) facets) and $\mathrm{Pd} / \mathrm{CeO}_{2}$-octahedra ((111) and (100) facets). An XPS study conducted by the same group revealed the formation of $\mathrm{Pd}^{2+-} \mathrm{O}^{2-}-\mathrm{Ce}^{4+}$ linkages on both $\mathrm{CeO}_{2}$-rods and $\mathrm{CeO}_{2}$-cubes but with a higher stability on the rods exposing (110) facets (Fig. 2) [34]. This linkage readily provided nucleophilic oxygen and created oxygen vacancies. In contrast, $\mathrm{PdO}_{x}$ nanoparticles are the dominant form of $\mathrm{Pd}$ species on the $\mathrm{CeO}_{2}$-octahedra exposing (111) surfaces (Fig. 2), which have a decreased tendency to form oxygen vacancies [34].

$\mathrm{Pt} / \mathrm{CeO}_{2}$ catalysts show low-temperature reactivity for $\mathrm{CO}$ oxidation from $20-80{ }^{\circ} \mathrm{C}$ [35-38]. A consensus is interfacial $\mathrm{Pt}-\mathrm{O}-\mathrm{Ce}$ moieties are the sites for the activation of $\mathrm{CO}$

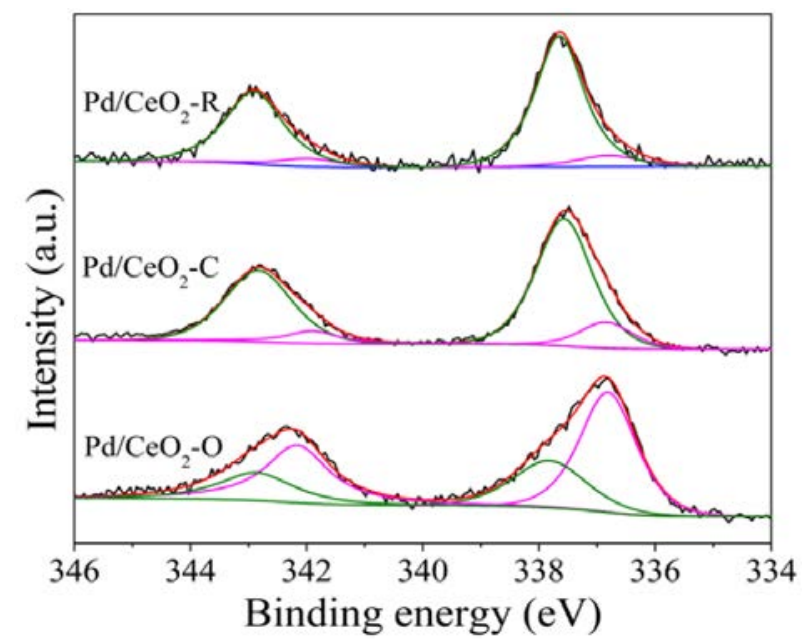

Fig. 2. XPS spectra of $\mathrm{Pd} 3 d$ on $\mathrm{Pd} / \mathrm{CeO}_{2}$-rods, $\mathrm{Pd} / \mathrm{CeO}_{2}$-cubes and $\mathrm{Pd} / \mathrm{CeO}_{2}$-octahedra catalysts. The deconvoluted peaks at $336.8 \mathrm{eV}$ (pink and $337.7 \mathrm{eV}$ (green) were assigned to $\mathrm{Pd}^{2+}$ and $\mathrm{PdO}_{x}$ species, respectively. Reprinted with permission from Ref. [34] copyright 2016, ACS Catalysis. 

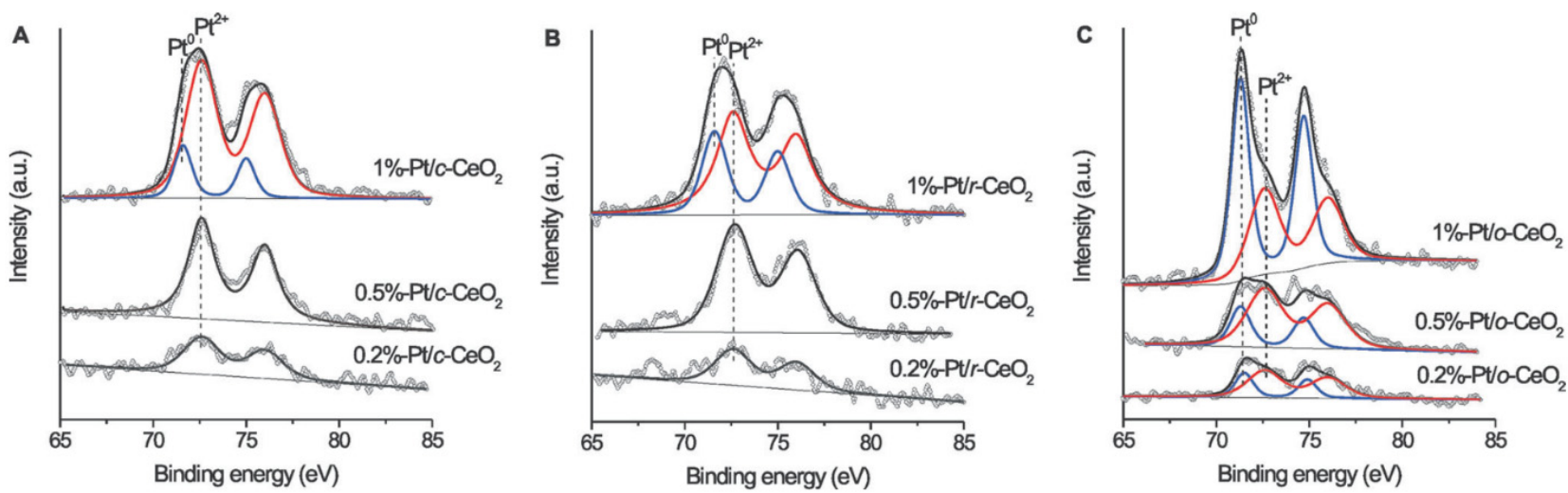

Fig. 3. XPS spectra of Pt $4 f$ of (A) Pt/CeO ${ }_{2}$-cubes, (B) $\mathrm{Pt} / \mathrm{CeO}_{2}$-rods and (C) $\mathrm{Pt} / \mathrm{CeO}_{2}$-octahedra catalysts. The deconvoluted peaks correspond to (blue) $\mathrm{Pt}^{0}$ and (red) $\mathrm{Pt}^{2+}$ species, respectively. Only $\mathrm{Pt}^{2+}$ species were observed on $\mathrm{Pt} / \mathrm{CeO}_{2}$-cubes and $\mathrm{Pt} / \mathrm{CeO}_{2}$-rods when the Pt weight loading was lower than $1 \%$. Reprinted with permission from Ref. [38], copyright 2013, ChemCatChem.

[35,36,38-40]. However, the charge state of the interfacial Pt during CO oxidation is still debated. Morfin et al. [41] applied DRIFTS measurements and identified $\mathrm{Pt}^{\delta+}$ and $\mathrm{PtO}$ species on $\mathrm{Pt} / \mathrm{CeO}_{2}$ catalysts synthesized from platinum tetraamine nitrate $\left(\mathrm{Pt}\left(\mathrm{NH}_{3}\right)_{4}\left(\mathrm{NO}_{3}\right)_{2}\right)$ and chloroplatinic acid $\left(\mathrm{H}_{2} \mathrm{PtCl}_{6}\right)$ precursors, respectively. The latter catalysts showed poor reactivity towards $\mathrm{CO}$ adsorption and they claimed $\mathrm{Pt}^{\delta+}(0<\delta<2)$ species interacting with the $\mathrm{CeO}_{2}$ support are more active than the deposited PtO species for CO oxidation. Similarly, Gao et al. [38] found the catalytic performance followed the order of $\mathrm{Pt} / \mathrm{CeO}_{2}$-rods $>\mathrm{Pt} / \mathrm{CeO}_{2}$-cubes $>\mathrm{Pt} / \mathrm{CeO}_{2}$-octahedra. However, as they increased the $\mathrm{Pt}$ weight loading on $\mathrm{CeO}_{2}$-rods and $\mathrm{CeO}_{2}$-cubes, the fraction of metallic $\mathrm{Pt}^{0}$ increased (Fig. 3) as well as the specific reaction rates (Table 1 ), which supported the conclusion that $\mathrm{Pt}^{0}-\mathrm{CeO}_{2}$ ensembles are more active than $\mathrm{Pt}^{2+}$. Apparent disagreements in the literature may be related to the effect of metal particle size, since distributions can seldom be kept constant in comparative experiments.

Theoretical DFT studies have also investigated the oxidation of CO over metal nanoclusters supported on ceria surfaces. Au-based catalysts have received the most attention with DFT calculations. Song et al. [42] modeled three different CO oxidation mechanisms over a 32 atom-Au nanorod supported on $\mathrm{CeO}_{2}(110)\left(\mathrm{Au}_{32} / \mathrm{CeO}_{2}(110)\right.$, Fig. 4). The first mechanism was a

Table 1

$\mathrm{Pt}$ loading, $\mathrm{Pt}^{0} / \mathrm{Pt}^{2+}$ ratio, and specific reaction rate of various $\mathrm{Pt} / \mathrm{CeO}_{2}$ catalysts. Reproduced with permission from Ref. [38], copyright 2013, ChemCatChem.

\begin{tabular}{lccc}
\hline Catalysts & $\begin{array}{c}\text { Pt loading } \\
\text { (wt } \%)\end{array}$ & $\begin{array}{c}\text { Specific reaction rate of } \\
\mathrm{Pt}^{0} / \mathrm{Pt}^{2+}\end{array}$ \\
$\begin{array}{l}\mathrm{CO} \text { oxidation }\left(40{ }^{\circ} \mathrm{C}\right) \\
\left(\mathrm{mmol}_{\mathrm{co}} \mathrm{mol}_{\mathrm{Pt}^{-1}} \mathrm{~s}^{-1}\right)\end{array}$ \\
\hline $0.2 \% \mathrm{Pt} / \mathrm{CeO}_{2}$-rod & 0.12 & 0 & 68 \\
$0.5 \% \mathrm{Pt} / \mathrm{CeO}_{2}$-rod & 0.33 & 0 & 118 \\
$1 \% \mathrm{Pt} / \mathrm{CeO}_{2}$-rod & 0.87 & 0.53 & 147 \\
$0.2 \% \mathrm{Pt} / \mathrm{CeO}_{2}$-cube & 0.14 & 0 & Very low \\
$0.5 \% \mathrm{Pt} / \mathrm{CeO}_{2}$-cube & 0.39 & 0 & 23 \\
$1 \% \mathrm{Pt} / \mathrm{CeO}_{2}$-cube & 0.88 & 0.22 & 40 \\
$0.2 \% \mathrm{Pt} / \mathrm{CeO}_{2}$-octahedra & 0.14 & 0.35 & Very low \\
$0.5 \% \mathrm{Pt} / \mathrm{CeO}_{2}$-octahedra & 0.32 & 0.4 & 18 \\
$1 \% \mathrm{Pt} / \mathrm{CeO}_{2}$-octahedra & 0.72 & 1.58 & 8 \\
\hline
\end{tabular}

Mars-van Krevelen (MvK) mechanism in which $\mathrm{CO}$ adsorbed at the $\mathrm{Au}$ nanorod- $\mathrm{CeO}_{2}$ interface, followed by reaction with a ceria lattice oxygen. The generated oxygen vacancy is refilled by adsorption of gas phase $\mathrm{O}_{2}$ and its facile dissociation (56 $\mathrm{kJ} /$ mol barrier) into a lattice 0 atom and a reactive 0 atom. The other two reaction paths start with $\mathrm{O}_{2}$ adsorption at the $\mathrm{Au}_{32} / \mathrm{CeO}_{2}(110)$ interface enabling the adsorbed $\mathrm{O}_{2}$ to either directly react with adsorbed $\mathrm{CO}$ in a Langmuir-Hinshelwood mechanism (co-adsorption mechanism) or dissociate first into 0 atoms that then react with CO (step-wise mechanism).

All three candidate mechanisms were reported to be relevant to $\mathrm{CO}$ oxidation catalysis due to very similar overall reaction barriers, with the $\mathrm{CeO}_{2}(110)$ surface facilitating $\mathrm{O}_{2}$ adsorption as well as dissociation in the stepwise mechanism. The proposed MvK mechanism is consistent with experimentally determined involvement of lattice 0 atoms in CO oxidation

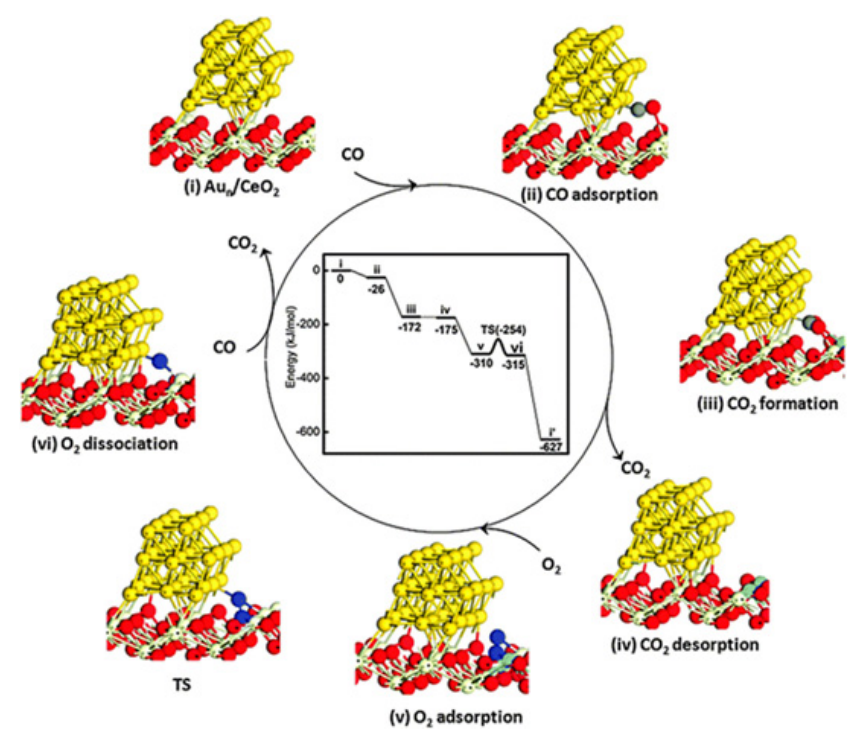

Fig. 4. DFT calculated reaction energy diagram with intermediate structures for Mars-van Krevelen (MvK) mechanism on $\mathrm{Au}_{32} / \mathrm{CeO}_{2}(110)$ Color code: green (reduced cerium, $\mathrm{Ce}^{3+}$ ), blue (adsorbed $\mathrm{O}_{2}$ molecule). The energies are relative to $\mathrm{Au}_{32} / \mathrm{CeO}_{2}+2 \mathrm{CO}(\mathrm{g})+\mathrm{O}_{2}(\mathrm{~g})$. Reprinted with permission from Ref. [42], copyright 2013, Catalysis Science \& Technology. 
[43]. The dominant mechanism may, however, vary on the different terminated ceria surfaces. For metal clusters supported on $\mathrm{CeO}_{2}(111)$, the MvK mechanism is not operative because of a less favorable oxygen vacancy formation energy than on the other $\mathrm{CeO}_{2}$ facets. Kim et al. [44] concluded the MvK mechanism may only dominate at high temperatures on $\mathrm{Au} / \mathrm{CeO}_{2}(111)$ catalysts, and this appears true even at $\mathrm{Au}$-defective $\mathrm{CeO}_{2}$ (111) interface [42]. In the co-adsorption mechanism, the structure of the intact $\mathrm{CeO}_{2}$ (111) surface would hinder $\mathrm{O}_{2}$ adsorption at the interface, therefore, $\mathrm{O}_{2}$ can only adsorb on the Au cluster [42]. The stepwise mechanism, requiring $\mathrm{O}_{2}$ dissociation at the interface, may also be difficult at the $\mathrm{CeO}_{2}(111)$ surface due to hindered $\mathrm{O}_{2}$ adsorption at the interface [44]. MvK-facilitated $\mathrm{CO}$ oxidation with $\mathrm{O}_{2}$ adsorption and activation occurring at $\mathrm{O}$ vacancies was also inferred over $\mathrm{CeO}_{2}(100)$ surface from a combined DFT and experimental work over ceria cubes modeled as $\mathrm{Au} / \mathrm{CeO}_{2}(100)$ [45].

In related work, Song et al. [46] examined the oxidation of $\mathrm{CO}$ over $\mathrm{Pd} / \mathrm{CeO}_{2}$ catalysts over a 32 atom-Pd nanorod model supported on a reactive surface termination of ceria, $\mathrm{CeO}_{2}(110)$. The entire MvK reaction mechanism for $\mathrm{CO}$ oxidation is similar to that over $\mathrm{Au}_{32} / \mathrm{CeO}_{2}(110)$ as described above, but the energetics of individual steps vary significantly. For $\mathrm{Pd}_{32} / \mathrm{CeO}_{2}$, the reaction of adsorbed $\mathrm{CO}$ with a lattice $\mathrm{O}$ atom proceeds with a barrier of $122 \mathrm{~kJ} / \mathrm{mol}$ and an exothermicity of $20 \mathrm{~kJ} / \mathrm{mol}$, in sharp contrast to the negligible reaction barrier and high exothermicity during CO oxidation over $\mathrm{Au}_{32} / \mathrm{CeO}_{2}(110)$ reported by the same group. The difference arises from a much stronger $\mathrm{Pd}-\mathrm{CO}$ bond. The barrier for $\mathrm{O}_{2}$ dissociation occurring at the metal/ceria interface is similar for $\mathrm{Au}_{32}$ and $\mathrm{Pd}_{32}$. Additionally, the latter half of the reaction cycle (CO reaction with dissociated $\mathrm{O}$ atoms) is different than on ceria-supported Au NPs. Dissociated $\mathrm{O}$ atoms migrate to the Pd NPs and adsorb more strongly than the 0 adsorbed at the $\mathrm{Au} /$ ceria interface. The barrier for the $\mathrm{CO}+\mathrm{O}$ reaction is very close to the reported barrier for CO oxidation on the Pd (111) surface [47]. The study also concluded the co-adsorption and stepwise mechanisms, operable on $\mathrm{Au}_{32} / \mathrm{CeO}_{2}(110)$, could be ruled out on the $\mathrm{Pd}_{32} / \mathrm{CeO}_{2}$ due to a stronger $\mathrm{CO}$ adsorption on $\mathrm{Pd}_{32}$, ultimately resulting in $\mathrm{CO}$ poisoning.

\subsection{Preferential oxidation of $\mathrm{CO}$ in the presence of $\mathrm{H}_{2}$}

For $\mathrm{CeO}_{2}$-supported metal catalysts, the selectivity towards $\mathrm{CO}$ in the presence of excess $\mathrm{H}_{2}$ requires selective $\mathrm{CO}$ adsorption and suppression of $\mathrm{H}_{2}$ adsorption. $\mathrm{Pd} / \mathrm{CeO}_{2}$ catalysts are remarkably active for $\mathrm{CO}$ oxidation, but the reactivity decreases drastically in the presence of $\mathrm{H}_{2}$ [48]. For example, under PROX conditions, the formation of Pd $\beta$-hydride was identified by Pozdnyakova et al. [49] using in situ XPS, and the hydride reacts rapidly with oxygen which suppressed $\mathrm{CO}$ oxidation. Increasing temperature led to higher $\mathrm{CO}_{2}$ selectivity on $\mathrm{Pd} / \mathrm{CeO}_{2}$ catalysts due to decomposition of the hydride.

$\mathrm{Pt} / \mathrm{CeO}_{2}$ catalysts are good candidates for $\mathrm{CO}$ PROX reactions in excess hydrogen. The key for $\mathrm{CO}_{2}$ selectivity was assumed to be the suppression of $\mathrm{H}_{2}$ adsorption, due to water accumulation on the catalyst surface and blockage of the oxida- tion sites for adsorbed $\mathrm{H}$ species [49,50]. As depicted by Pozdnyakova-Tellinger et al. [49,51], hydrogen spillover from $\mathrm{Pt}$ to the ceria support leads to formation of oxygen vacancies and surface water stabilized at the vacancies. The adsorbed water blocked subsequent adsorption of hydrogen at the vacant sites, while CO mainly adsorbed to metallic platinum. Gao et al. [38] compared the activity of Pt supported on different $\mathrm{CeO}_{2}$ nanostructures for $\mathrm{CO}$ PROX and found the activity increases in the order octahedra < cubes < rods, which is consistent with the order of oxygen vacancy concentration as characterized by the intensity of the corresponding Raman bands. This result further emphasizes the role of oxygen vacancies in the oxidation of $\mathrm{CO}$. In the above work, $\mathrm{Pt} / \mathrm{CeO}_{2}$ reaches $\mathrm{CO}_{2}$ selectivity of $50 \%-80 \%$ below $50{ }^{\circ} \mathrm{C}$ when $\mathrm{CO}$ makes up $\sim 1 \%$ of the feed stream. However, Polster et al. [39] found the selectivity decreases to $20 \%$ as the CO fraction drops to $\sim 100$ ppm, which indicates $\mathrm{Pt} / \mathrm{CeO}_{2}$ catalysts are inadequate for the PROX reaction with trace quantities of $\mathrm{CO}$. The poor behavior at ultra-low $\mathrm{CO}$ concentration was explained by a change in reaction regime, as the reaction order of $\mathrm{O}_{2}$ was 0.58 at low $\mathrm{CO}$ coverage (25 ppm) and $\sim 0.02$ at higher concentration (1\%). This reaction order change indicates a change of rate limiting step, coverage regime, or a different reaction mechanism as the CO partial pressure varies. The authors proposed CO oxidation occurs on the Pt nanoparticles through a Langmuir-Hinshelwood (L-H) mechanism at low CO concentrations, whereas $\mathrm{CO}$ oxidation at higher concentrations occurred at the Pt-O-Ce interface through a Mars van Krevelen (MvK) mechanism [39]. In-situ DRIFTS demonstrate the adsorbed CO peak saturated at $650 \mathrm{ppm} \mathrm{CO}$, and was unaffected by the presence of $\mathrm{O}_{2}$. This suggests the Pt surface becomes completely covered by $\mathrm{CO}$ at rather low $\mathrm{CO}$ pressures and reaction only occurs through MvK mechanism at the interface once the Pt surface is CO saturated. At low $\mathrm{CO}$ pressures where a L-H mechanism dominates, the rate of $\mathrm{H}_{2}$ oxidation is significant as open $\mathrm{Pt}$ surface sites can also activate $\mathrm{H}_{2}$ to react with bound $\mathrm{O}$ atoms [39].

The performance of $\mathrm{Au} / \mathrm{CeO}_{2}$ catalysts towards $\mathrm{CO}-\mathrm{PROX}$ is highly dependent on the catalyst preparation method, and reported performance also varies among catalysts prepared by the same method. Luengnaruemitchai et al. [52] synthesized $1 \% \mathrm{Au} / \mathrm{CeO}_{2}$ by co-precipitation, impregnation and sol-gel methods and the catalysts prepared by co-precipitation possessed both the highest $\mathrm{CO}$ conversion and selectivity as well as long-term stability. A temperature-programmed reduction (TPR) study by Arena et al. [53] indicated $\mathrm{Au} / \mathrm{CeO}_{2}$ synthesized by deposition-precipitation or combustion (urea ignition) showed higher activity than those synthesized by co-precipitation or incipient wetness. Scirè et al. [54] also found synthesis by deposition-precipitation resulted in more active and stable catalysts compared to co-precipitation. These conflicting results can be traced back to differences in Au dispersion, support surface area and removal of poisons, especially chloride, which arises from the common Au precursor, $\mathrm{HAuCl}_{4}$. High $\mathrm{Au}$ dispersions are clearly desirable, while co-precipitation can result in too much Au buried beneath the surface. Support surface area is important because higher sur- 
face area suggests a greater number of adsorption sites for small NPs. Chloride removal down to a few ppm is critical because $\mathrm{Au}$ chlorides are resistant to reduction except at higher temperatures. Deposition-precipitation can sometimes result in easier chloride removal because the chlorides can be replaced by other ligands prior to surface deposition. Many of these competing effects can be delineated through XPS or even chemisorption techniques.

Deng et al. [55] synthesized low-content $(\mathrm{Au}<0.6$ at\%) $\mathrm{Au} / \mathrm{CeO}_{2}$ via urea gelation/co-precipitation and deposition-precipitation followed by $\mathrm{NaCN}$ leaching for the removal of weakly bound gold. These catalysts possessed activity for CO-PROX, good redox cyclability, and stability over a wide range of temperatures. An XPS study showed all strongly-bound gold was cationic, and these cationic sites were involved in catalyzing the PROX reaction. Beyond conventional synthesis methods, Cargnello et al. [56] introduced carboxylic groups on the surface of monolayer-protected gold nanoparticles to direct ceria growth through covalent bonding between ceria and the carboxylic group (Fig. 5). They reported higher dispersion of $\mathrm{Au}$ nanoparticles and activity in the CO-PROX reaction, but lower accessibility of $\mathrm{Au}$ nanoparticle than the $\mathrm{Au} / \mathrm{CeO}_{2}$ catalyst synthesized by deposition-precipitation. The $\mathrm{Au}$ nanoparticles were at least partly encapsulated, with a portion completely buried in the nanostructured porous ceria [56].

The application of $\mathrm{CuO} / \mathrm{CeO}_{2}$ in $\mathrm{CO}$ PROX reactions was firstly reported by Avgouropoulos et al. [57], who prepared catalysts showing remarkable selectivity, activity, stability and tolerance to $\mathrm{CO}_{2}$. There is significant synergy between $\mathrm{CuO}$ and $\mathrm{CeO}_{2}$ since $\mathrm{CuO} / \mathrm{CeO}_{2}$ shows much higher $\mathrm{CO}$ oxidation activity than either $\mathrm{CuO}$ or $\mathrm{CeO}_{2}$ [13]. Comparison of $\mathrm{CuO} / \mathrm{CeO}_{2}$ catalysts with $\mathrm{Au} / \mathrm{CeO}_{2}$ demonstrate they can possess better $\mathrm{CO}_{2}$ selectivity in spite of lower activity $[54,57,58]$. Similar to $\mathrm{Au} / \mathrm{CeO}_{2}$, the activity of $\mathrm{CuO} / \mathrm{CeO}_{2}$ catalysts is highly dependent on the synthetic approach and parameters such as calcination temperature and loading, as summarized in a previous review [59]. For example, Chung et al. [60] prepared $\mathrm{CuO} / \mathrm{CeO}_{2}$ catalysts by co-precipitation at various $\mathrm{pH}$ values, and found higher $\mathrm{pH}$ led to a greater rate of $\mathrm{CeO}_{2}$ nucleation, and increased concentration of interfacial $\mathrm{Cu}$ sites, reducibility of $\mathrm{CuO}$ and $\mathrm{CO}$ oxidation activity. Jung et al. [61] studied the influence of calcination temperature $\left(500-900{ }^{\circ} \mathrm{C}\right)$ of $\mathrm{CuO} / \mathrm{CeO}_{2}$ prepared by co-precipitation. They found a volcano relationship between activity and calcination temperature with an optimum at 700 ${ }^{\circ} \mathrm{C}$. Above $800{ }^{\circ} \mathrm{C}$, phase separation between $\mathrm{CuO}$ and $\mathrm{CeO}_{2}$ was

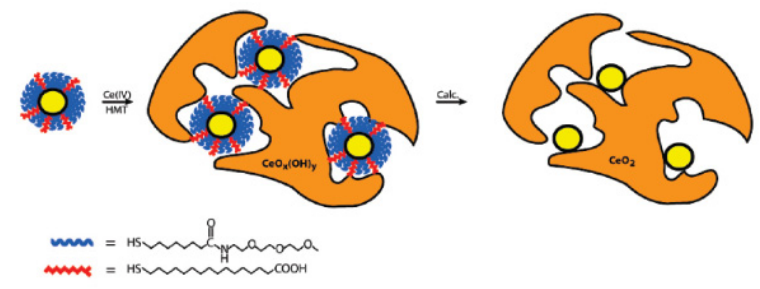

Fig. 5. Schematic representation of $\mathrm{Au} / \mathrm{CeO}_{2}$ catalysts prepared by directed growth of ceria around carboxyl-grafted $\mathrm{Au}$ nanoparticles, as described by Cargnello et al. Reprinted with permission from Ref. [56], copyright 2010, Chemistry of Materials. detected by XRD and $\mathrm{H}_{2}$-TPR. This demixing decreased the quantity of active $\mathrm{Cu}-\mathrm{Ce}-\mathrm{O}$ species and decreased the activity for CO PROX. Maciel et al. [62] compared the activity of $\mathrm{CuO} / \mathrm{CeO}_{2}$ synthesized by a hydrothermal or precipitation approach with observation of higher activity and selectivity on the former catalysts. They attributed this to a smaller crystallite size of the hydrothermally-prepared catalysts, leading to better reducibility of the $\mathrm{CuO}$ nanoparticles, as characterized by SEM and $\mathrm{H}_{2}$-TPR.

Martinez-Arias and co-workers [63,64] studied various synthetic approaches to alter the interfacial area between $\mathrm{CuO}_{x}$ and $\mathrm{CeO}_{2}$, and thereby demonstrated, using multiple characterization techniques, that selective $\mathrm{CO}$ oxidation takes place at interfacial sites between $\mathrm{CeO}_{2}$ and dispersed $\mathrm{CuO}_{x}$. A correlation was established between PROX activity and the extent of reduction of the $\mathrm{CuO}_{x}$ entities. The $\mathrm{H}_{2}$ oxidation was also shown to proceed immediately (thereby lowering CO oxidation) after onset of a major copper reduction to $\mathrm{Cu}^{+}$, indicating the active species for $\mathrm{H}_{2}$ oxidation include partially reduced and dispersed copper oxide NPs, as well as fully reduced $\mathrm{Cu}(0)$. XANES results (Fig. 6) illustrate how the onset of measurable interfacial $\mathrm{Cu}^{+}$corresponds to the onset of $\mathrm{CO}$ oxidation, while the bulk evolution of (first) $\mathrm{Cu}^{+}$and (second) $\mathrm{Cu}(0)$ correlates with the oxidation of $\mathrm{H}_{2}$.

Guo et al. [65] followed up on this work, preparing ceria nanoparticles with rod, cube, plate and polyhedral morphology by hydrothermal methods to support $\mathrm{CuO}_{x}$. The $\mathrm{CuO} / \mathrm{CeO}_{2}$-rod and $\mathrm{CuO} / \mathrm{CeO}_{2}$-polyhedra catalysts displayed better low-temperature activity for CO PROX and a broader temperature range for high CO conversion. XPS revealed a higher con-

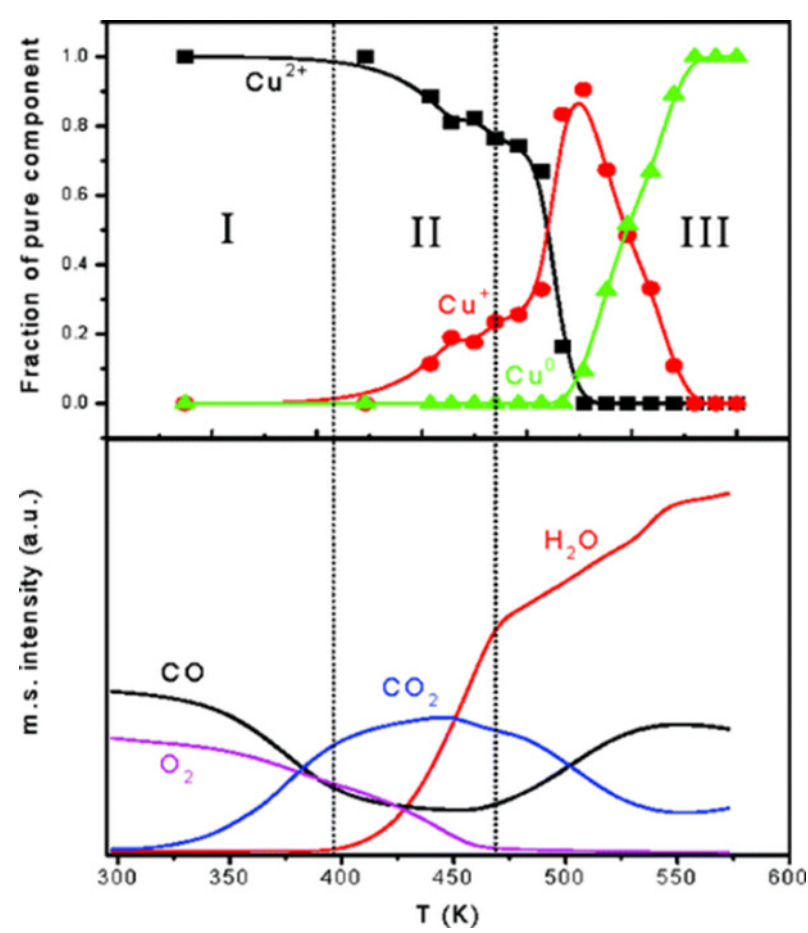

Fig. 6. Evolution of principal components detected by XANES during a CO-PROX over $\mathrm{Cu}_{0.2} \mathrm{Ce}_{0.8} \mathrm{O}_{2}$ and evolved gases during the same run. Reprinted with permission from Ref. [63], copyright 2007, Journal of the American Chemical Society. 
tent of $\mathrm{Cu}^{+}$species in the more active catalysts, while Raman spectroscopy showed a higher concentration of oxygen vacancies, many of which would be located at interface sites. They also performed in situ DRIFTS measurements and inferred stronger metal-support interactions based on a weaker C-O bond in $\mathrm{Cu}^{+}-\mathrm{CO}$ species [65]. These results are consistent with those of Martinez-Arias and represent another example of the influence of $\mathrm{CeO}_{2}$ morphology on catalytic activity [63,64].

Preferential $\mathrm{CO}$ oxidation over $\mathrm{H}_{2}$ has also been studied with DFT methods over ceria supported copper catalysts. The DFT calculations using $\mathrm{CuO} / \mathrm{CeO}_{2}$ models demonstrate $\mathrm{CuO}{ }_{x}$ clusters on $\mathrm{CeO}_{2}(111)$ were easily reduced to $\mathrm{Cu}^{+}$, improving the catalytic reactivity relative to $\mathrm{CuO}_{x} / \mathrm{CeO}_{2}(001)$ which maintained $\mathrm{Cu}$ in $\mathrm{a}+2$ oxidation state [66]. The facet-dependent reducibility during the PROX reaction has also been substantiated by DFT calculations on a $\mathrm{Ce}_{60} \mathrm{O}_{120}$ cluster model [67]. DFT results show enrichment of oxygen vacancies at the sites located at the intersection of (111) and (002) facets. A high concentration of $\mathrm{Ce}^{3+}$ species (Table 2) at the $(111) /(002)$ intersection induces the formation of $\mathrm{Cu}^{+}\left(\mathrm{Cu}^{2+}+\mathrm{Ce}^{3+} \rightarrow \mathrm{Cu}^{1+}+\mathrm{Ce}^{4+}\right)$. For $\mathrm{CuO} / \mathrm{CeO}_{2}$ (spheres) and $\mathrm{CuO} / \mathrm{CeO}_{2}$ (spindles), such intersections are exposed, with positive effects on PROX activity. These two catalysts possessed a wider temperature window for complete $\mathrm{CO}$ conversion than other $\mathrm{Cu} / \mathrm{CeO}_{2}$-based catalysts (rods, octahedra) comprised primarily of less reducible facets [68]. The higher temperature window for PROX was further explained by DFT calculations demonstrating $\mathrm{CuO}_{x}$ nanoparticles interacted more strongly with the $\mathrm{CeO}_{2}$ surface, thereby making them highly resistant towards reduction to $\mathrm{Cu}(0) . \mathrm{Cu}(0)$ is responsible for $\mathrm{H}_{2}$ activation and thus its presence contributes to $\mathrm{CO}_{2}$ selectivity loss. The catalytic synergy for PROX on $\mathrm{Cu} / \mathrm{CeO}_{2}$ therefore arises from a combination of high surface area, a stable $\left(\mathrm{Cu}^{+}\right.$or $\mathrm{Cu}^{\left(2-\delta^{-}\right)}$in the oxidized form $)$oxidation state of copper, high concentration of oxygen vacancies, as well as a strong interaction between $\mathrm{CuO}_{x}$ and $\mathrm{CeO}_{2-x}$ [67].

Jing et al. [69] reported improved catalytic performance for PROX, including an expanded temperature window, with $\mathrm{Au} / \mathrm{CeO}_{2}-\mathrm{CuO}$ compared to $\mathrm{CuO} / \mathrm{CeO}_{2}$ catalysts. On the basis of DFT calculations, Au clusters were expected to be mainly located on the $\mathrm{CeO}_{2}$ (111) surfaces. The better performance was attributed to these $\mathrm{Au}$ species both stabilizing $\mathrm{CuO}_{x}$ against reduction and promoting the reduction of ceria to supply active lattice oxygen. Prevention of the reduction of copper species hindered $\mathrm{H}_{2}$ oxidation. DFT results demonstrated an increase in $\mathrm{Au}$ content led to an increase in the number of active interfacial sites and thus decreases the activation barrier for CO oxidation, consistent with experimental observations.

\section{Table 2}

Calculated GGA and GGA+U (U = $5 \mathrm{eV}$ ) energies for oxygen vacancy formation energy $\left(E_{\mathrm{vac}}\right)$ on different $\mathrm{CeO}_{2}$ surfaces. Reproduced with permission from Ref. [67], Copyright 2018, Applied Catalysis B: Environmental. Elsevier.

\begin{tabular}{lcc}
\hline $\mathrm{CeO}_{2}$ facet & $\mathrm{GGA}(\mathrm{eV})$ & $\mathrm{GGA}+\mathrm{U}(\mathrm{eV})$ \\
\hline$(111)$ & 1.69 & 3.23 \\
$(002)$ & 0.67 & 2.81 \\
$(111) /(002)$ & 0.59 & 2.39 \\
\hline
\end{tabular}

\section{3. $\mathrm{CO}$ oxidation on $\mathrm{CeO}_{2}$-supported single atom catalysts}

CO oxidation represents a good probe reaction of ceria-supported single-atom catalysts since work on supported nanoparticle catalysts demonstrate the influence of support properties and the identity of the metal on the observed performance. Single atoms are less effective for the dissociative adsorption of $\mathrm{H}_{2}$, which contributes to the selectivity towards $\mathrm{CO}_{2}$ during PROX [70]. Due to a limited number of reported work on the application of $\mathrm{CeO}_{2}$-supported single atom catalysts in the CO PROX reaction, CO PROX will be discussed along with $\mathrm{CO}$ oxidation.

$\mathrm{Pt}_{1} / \mathrm{CeO}_{2}$ has been extensively studied, but it is unclear whether single atoms are more (or less) active than Pt clusters. We also compare to studies considering $\mathrm{Pt}_{1} / \mathrm{TiO}_{2}$ catalysts, since $\mathrm{TiO}_{2}$ can similarly serve as a redox-active support. Ding et al. [71] claimed Pt single atoms on active supports showed little low-temperature activity due to their strong binding of CO. They intentionally synthesized $\mathrm{Pt} / \mathrm{TiO}_{2}$ with different $\mathrm{Pt}$ weight loadings to guarantee the coexistence of Pt nanoparticles and single atoms, and performed in situ FTIR to compare the binding strength of $\mathrm{CO}$ on both Pt species. After saturation of both Pt sites with CO, and a He purge, the band related to Pt nanoparticles decreased quickly while the band associated with CO bound to single Pt atoms remained (Fig. 7) [71]. However, DeRita et al. [72] suggested the Pt species binding CO strongly may actually be small oxidized Pt clusters formed at elevated temperatures under oxidative conditions, whereas Pt single atoms pre-reduced in $\mathrm{H}_{2}$ bind $\mathrm{CO}$ weakly [73]. In situ FTIR spectra revealed CO adsorbed on Pt single atoms quickly diminished upon Helium purge at room temperature (Fig. 8(A)), whereas CO adsorbed on Pt nanoparticles and oxidized Pt clusters desorbed under temperature-programmed oxidation conditions (Fig. 8(B) and $8(\mathrm{C})$ ). The reduced $\mathrm{Pt}_{1} / \mathrm{TiO}_{2}$ catalysts showed 2-fold greater turnover frequency than $1 \mathrm{~nm}$ Pt clusters, but poorer stability [73]. The effect of hydrogen reduction was also studied by $\mathrm{Li}$ et al. [74] on $\mathrm{Pt}_{1} / \mathrm{CeO}_{2}$ catalysts, who applied in-situ DRIFTS, XAS and XPS techniques on $\mathrm{Pt}_{1} / \mathrm{CeO}_{2}$ catalysts pre-reduced in $5 \% \mathrm{H}_{2} / \mathrm{Ar}$ at $350{ }^{\circ} \mathrm{C}$. They identified

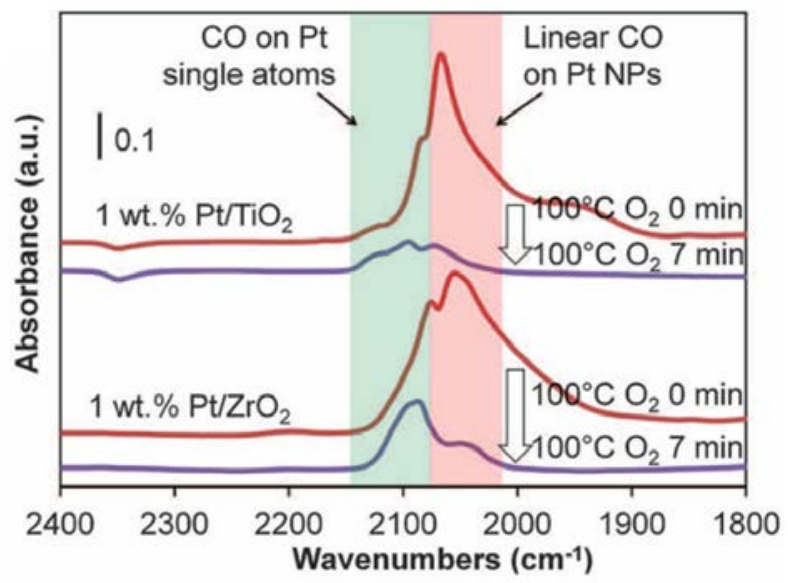

Fig. 7. IR spectra of $\mathrm{CO}$ adsorbed $\mathrm{Pt}$ single atoms and nanoparticles on wet-impregnated $\mathrm{Pt} / \mathrm{TiO}_{2}$ and $\mathrm{Pt} / \mathrm{ZrO}_{2}$ upon $\mathrm{O}_{2}$ exposure at $100{ }^{\circ} \mathrm{C}$. Reprinted with permission from Ref. [71], copyright 2015, Science. 

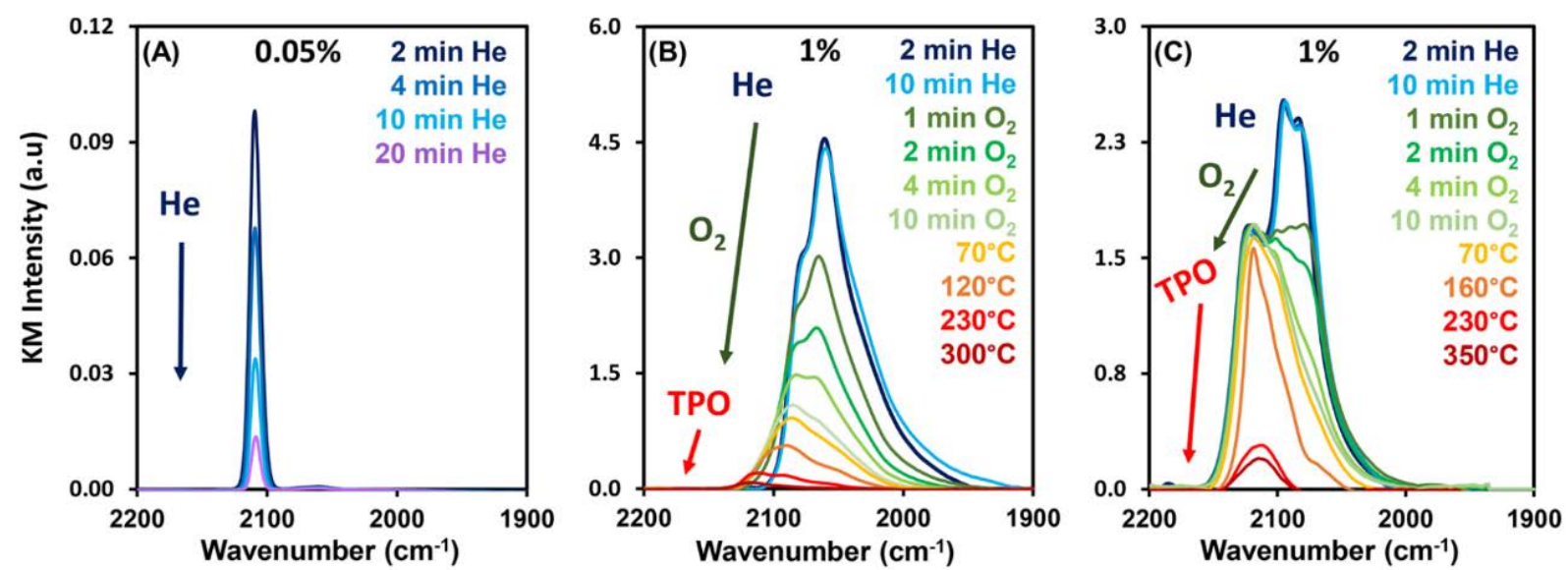

Fig. 8. DRIFTS spectra of $(\mathrm{A}) \mathrm{CO}$ adsorbed at room temperature and saturation coverage on a pre-reduced $0.05 \mathrm{wt} \% \mathrm{Pt}_{1} / \mathrm{TiO}_{2}$ single-atom catalysts, $(\mathrm{B}$ $\mathrm{CO}$ adsorbed to a reduced $1 \mathrm{wt} \% \mathrm{Pt} / \mathrm{TiO}_{2}$ catalyst during He purge and $\mathrm{TPO}$ ramp, (C) $\mathrm{CO}$ adsorbed to an oxidized $1 \mathrm{wt} \% \mathrm{Pt} / \mathrm{TiO}{ }_{2}$ catalyst during He purge and TPO ramp. Reprinted with permission from Ref. [73], copyright 2017, Journal of the American Chemical Society.

the dynamic formation of bimetallic Pt-Ce sites as a new type of active species during hydrogen reduction, which was critical for the subsequent oxidation reaction.

Water was reported to improve the reactivity of the atomically dispersed ionic $\mathrm{Pt}^{2+}$ in $\mathrm{CO}$ oxidation. The promoting effect of water was first studied by Wang et al. [75] by pulsing $\mathrm{CO}$ and ${ }^{16} \mathrm{O}_{2}$ with isotopically-labeled $\mathrm{H}_{2}{ }^{18} \mathrm{O}$. They detected nearly half the amount of $\mathrm{CO}_{2}$ product in the form of $\mathrm{C}^{16} \mathrm{O}^{18} \mathrm{O}$ and the formation of $\mathrm{H}_{2}{ }^{16} \mathrm{O}$ at $98{ }^{\circ} \mathrm{C}$, which indicated water was directly involved in the reaction. The DFT results suggested formation of a carboxyl intermediate as water dissociated into $\mathrm{H}$ and hydroxyl groups, the latter of which interacted with adsorbed $\mathrm{CO}$ on Pt single sites (Fig. 9) [75]. Nie et al. [76] treated $\mathrm{Pt}_{1} / \mathrm{CeO}_{2}$ with steam at $750{ }^{\circ} \mathrm{C}$ to improve the $\mathrm{CO}$ oxidation activity, which was sustained even in the absence of further water for over 300 h. $\mathrm{H}_{2}$-TPR results showed steam treatment created a new type of activated oxygen species, which according to DFT calculations was a surface hydroxyl $\left(\mathrm{O}_{\text {lattice }}[\mathrm{H}]\right)$ [76]. From DFT calculations, an oxygen vacancy migrated to the vicinity of a $\mathrm{Pt}$ single atom, a water molecule filled the vacancy with an oxygen atom, and the hydrogen atoms reacted with lattice oxygen atoms in $\mathrm{CeO}_{2}$ to form $\mathrm{O}_{\text {lattice }}[\mathrm{H}]$ (Fig. 9). The catalyst was stable up to $800{ }^{\circ} \mathrm{C}$ in an oxidizing environment [76].

$\mathrm{Au}_{1} / \mathrm{CeO}_{2}$ also showed good reactivity and stability for $\mathrm{CO}$ oxidation, as well as $\mathrm{CO}_{2}$ selectivity in CO PROX. Wang et al. [77] reported $0.12 \mathrm{wt} \% \mathrm{Au}_{1} / \mathrm{CeO}_{2}$ showed $90 \%$ CO conversion at $90{ }^{\circ} \mathrm{C}$, and stability over $1000 \mathrm{~min}$. time-on-stream, which they attributed to strong metal-support interactions between $\mathrm{Au}_{1}$ and $\mathrm{CeO}_{2}$. Qiao et al. [70] reported $\mathrm{Au}_{1} / \mathrm{CeO}_{2}$ was highly active, $\mathrm{CO}_{2}$-selective with greater stability than supported $\mathrm{Au}$ nanoparticles; single atoms supported on $\mathrm{CeO}_{2}$ displayed $>99.5 \%$ CO conversion over a wide temperature range with
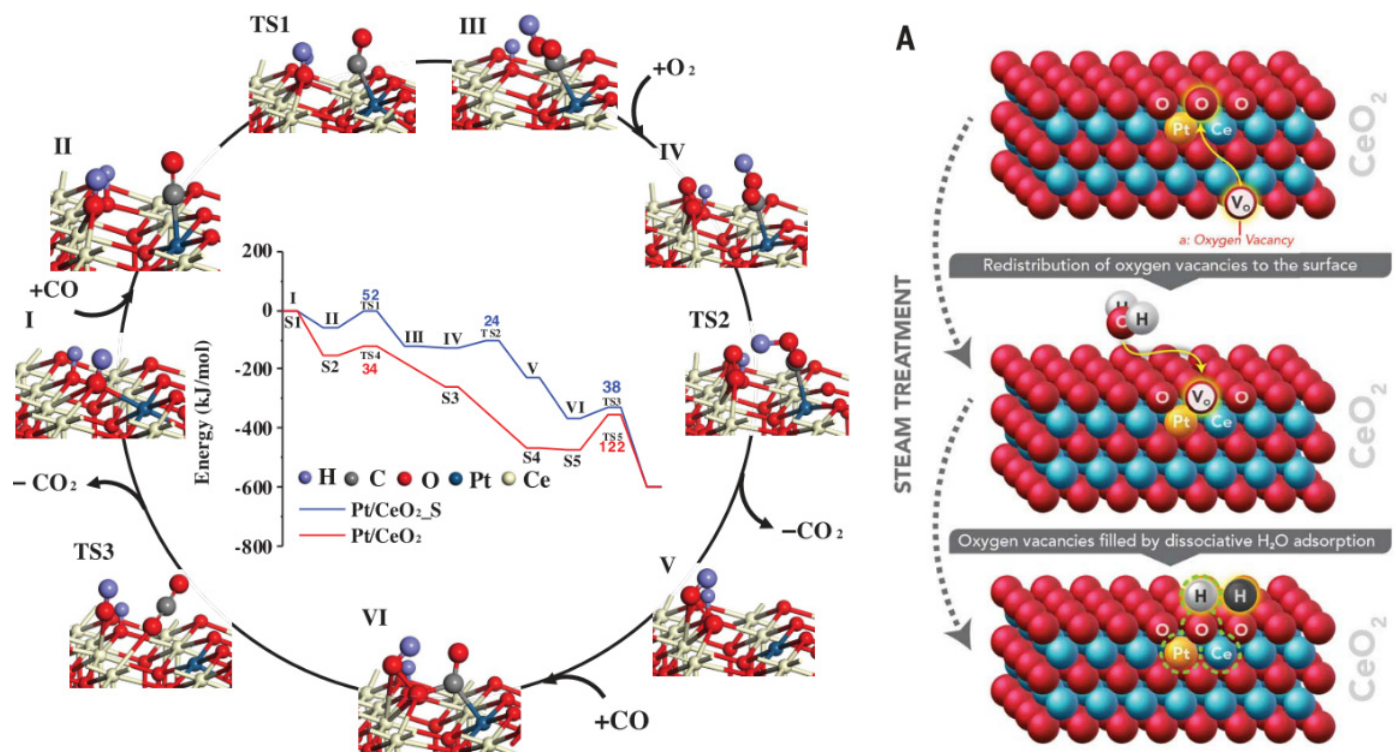

Fig. 9. Left: DFT simulated reaction mechanism for $\mathrm{CO}$ oxidation on steam-treated $\mathrm{Pt}_{1} / \mathrm{CeO}_{2}$ (111) surface. Right: illustration of steam-treatment effects on the atomically dispersed $\mathrm{Pt}_{1} / \mathrm{CeO}_{2}$ catalysts. Reprinted with permission from Ref. [76], copyright 2017, Science. 
almost zero $\mathrm{H}_{2}$ conversion. DFT calculations for $\mathrm{H}_{2}$ oxidation on $\mathrm{Au}_{1} / \mathrm{CeO}_{2}$ suggested an Eley-Rideal mechanism with a much higher activation barrier than $\mathrm{CO}$ oxidation, indicating single atoms of Au cannot effectively dissociate $\mathrm{H}_{2}$ [70].

CO oxidation on single Pd atoms supported on rod- and cube-shaped ceria nanostructures was investigated by Spezzati et al. [78,79]. A 1 wt $\% \mathrm{Pd}_{1} / \mathrm{CeO}_{2}$ (111) catalyst showed reactivity at temperatures as low as $50{ }^{\circ} \mathrm{C}$, and DFT calculations revealed the reaction proceeded through a catalytic redox cycle with $\mathrm{PdO}$ and $\mathrm{PdO}_{2}$ as the active species [78]. $\mathrm{Pd}_{1} / \mathrm{CeO}_{2}(100)$ was less active than $\mathrm{Pd}_{1} / \mathrm{CeO}_{2}$ (111) due to a lower fraction of active $\mathrm{Pd}$ species, i.e. single Pd atoms in the oxidized form [79]. DFT calculations of $\mathrm{CO}$ oxidation on $\mathrm{Pd}_{1} / \mathrm{CeO}_{2}(100)$ indicate the catalytic cycle requires the participation of lattice oxygen from $\mathrm{CeO}_{2}$ [79]. $\mathrm{Pd}_{1} / \mathrm{CeO}_{2}$ (111), however, is reported to follow a Langmuir Hinshelwood mechanism (co-adsorbing $\mathrm{CO}$ and $\mathrm{O}_{2}$ ) to generate active species $\mathrm{PdO}$ and $\mathrm{PdO}_{2}$. Consequently, the activation barrier for $\mathrm{CO}$ oxidation for $\mathrm{Pd} / \mathrm{CeO}_{2}$ (111) was much lower $(29 \mathrm{~kJ} / \mathrm{mol})$ compared to the barrier on $\mathrm{CeO}_{2}(100)$ (highest barrier $63 \mathrm{~kJ} / \mathrm{mol}$ ), consistent with the higher $\mathrm{CO}$ oxidation activity at $\mathrm{Pd} / \mathrm{CeO}_{2}$ (111) observed experimentally.

Based on the above results, $\mathrm{PdO}_{x}$ species on $\mathrm{CeO}_{2}$ (111) should be more active for $\mathrm{CO}$ oxidation than $\mathrm{Pd}$ adatom species on ceria which was supported by DFT studies and microkinetic simulations at $27^{\circ} \mathrm{C}$ [80]. However, $\mathrm{Pd}$ doped into $\mathrm{CeO}_{2}$ (square planar) should be less active due to weaker adsorption of $\mathrm{CO}$, no matter the surface facet. For Pd-doped $\mathrm{CeO}_{2}(110)$, Song et al. [46] reported CO adsorption occurs on the stoichiometrically-doped surface only. After the lattice oxygen is removed to form $\mathrm{CO}_{2}$ via a MvK mechanism, the doped Pd relocates to a subsurface position such that $\mathrm{O}$ atoms repel $\mathrm{CO}$ and inhibit its adsorption. They also reported DFT studies for CO oxidation over Pd single atoms on $\mathrm{CeO}_{2}$ (110) surfaces (Fig. 10) in parallel with the studies over Pd nanorod clusters supported on the same ceria facet (cited in the CO oxidation over NP section). The $\mathrm{Pd}^{2+}$ single atom sits in a 4-fold hollow site resulting in two



Fig. 10. Reaction mechanism of $\mathrm{CO}$ oxidation on the $\mathrm{Pd}_{1} / \mathrm{CeO}_{2}(110)$ model. (color scheme: gray $=\mathrm{C}$, red $=0$; white $=\mathrm{Ce}^{4+}$; cyan $=\mathrm{Ce}^{3+}$; blue $=$ $\mathrm{Pd})$. The electron density difference plot for $\mathrm{CO}$ adsorption on $\mathrm{Pd}_{1} / \mathrm{CeO}_{2}(110)$ is inserted next to the structure (state ii). The blue and yellow colors indicate respectively a decrease and an increase in the electron density. Reprinted with permission from Ref. [46], copyright 2015, Journal of Physical Chemistry C.
$\mathrm{Ce}^{3+}$ atoms, and adsorbs CO weakly. However, once $\mathrm{CO}$ is adsorbed, $\mathrm{Pd}$ adatoms adjacent to $\mathrm{O}$ atoms of the ceria surface, facilitate the formation of $\mathrm{CO}_{2}$ more so than Pd NPs. Since the dissociative adsorption of $\mathrm{O}_{2}$ is much stronger on Pd NPs than Pd adatoms ( -158 vs $-77 \mathrm{~kJ} / \mathrm{mol}$ ), strong 0 binding also makes the oxidation step more difficult on Pd NPs. Therefore, despite the weaker $\mathrm{CO}$ and $\mathrm{O}$ adsorption, atomically dispersed Pd on $\mathrm{CeO}_{2}(110)$ are more active than NPs.

The mechanism of $\mathrm{CO}$ oxidation on $\mathrm{Au}$ adatoms over ceria surfaces has been studied by DFT. Song et al. [81] postulated a mechanistically similar (to adatom $\mathrm{Pd} / \mathrm{CeO}_{2}$ ) MvK catalytic cycle on $\mathrm{Au}$ adatoms on $\mathrm{CeO}_{2}(110)$. Details of the surface termination of the ceria support were considered crucial. CO oxidation over single $\mathrm{Au}$ adatoms on $\mathrm{CeO}_{2}(111)$ appeared to be impossible due to difficulty in $\mathrm{O}_{2}$ dissociation in the second half of the MvK cycle (healing the O-vacancy and CO removal as $\mathrm{CO}_{2}$ with the dissociated $\mathrm{O}$ adatom). However, on $\mathrm{Au} / \mathrm{CeO}_{2}(110)$, the more open surface allowed for the coordination of $\mathrm{O}_{2}$ between the $\mathrm{Au}$ adatom and the vacancy site. Furthermore, $\mathrm{Au}$ adatoms are reported to be negatively charged on oxygen deficient $\mathrm{CeO}_{2-x}(111)$ [82]. Considering the typical dominance of the (111) surface in larger particles, this may explain the observation that sintering of $\mathrm{Au}$ atoms into clusters sometimes leads to an increase in the catalytic activity, as other reaction pathways become accessible as described in Section 2. Reactivity of $\mathrm{Au}$ adatoms for $\mathrm{CO}$ oxidation has been reported over step sites on a $\mathrm{CeO}_{2}$ (111) slab (by adding a $\mathrm{Ce}_{6} \mathrm{O}_{12}$ wire) [83], but again CO oxidation by lattice oxygen is found to be the rate-determining step $(0.83 \mathrm{eV})$. Recently, Wang et al. postulated, on the basis of ab initio MD simulations at temperatures of 300 and $700 \mathrm{~K}$, a new catalytic mechanism involving single atoms for $\mathrm{CO}$ oxidation on $\mathrm{Au} / \mathrm{CeO}_{2}$ (111) catalysts, arising from a transient $\mathrm{Au}^{+-} \mathrm{CO}$ reaction species $[83,84]$. During the oxidation of $\mathrm{CO}$, the $\mathrm{Au}^{+}$acts as a charge acceptor for $\mathrm{CO}$. This $\mathrm{Au}^{+} / \mathrm{CO}$ species considerably lowers the barrier for $\mathrm{CeO}_{2}$ reduction, thereby facilitating oxygen adsorption.

\section{Conclusions}

Supporting metal species on $\mathrm{CeO}_{2}$ tremendously boosts the reactivity and increases the low-temperature performance towards CO oxidation. Metal deposition on a ceria surface creates an active interface and the metal-support synergy can provide a viable reaction route following a Mars van Krevelen mechanism, where the supported metals serve as adsorption sites for $\mathrm{CO}$, which is oxidized by interfacial oxygen. Metal-support interactions may lead to positively charged metal species, which show much higher reactivity and selectivity compared to $\mathrm{CO}$ oxidation on metallic nanoparticles, even though they may both follow Langmuir-Hinshelwood mechanism. Reactivity towards the oxidation of $\mathrm{CO}$ is dependent on the dispersion of metal species, the chemical properties of the ceria support, and the extent of metal-support interaction, all of which can be tuned by the structural and chemical properties of the ceria support. Details of the catalyst synthetic methods control such properties, for example choice of metal precursors, how they initially interact with the supports, and pre- 
treatment conditions before reaction. Compared to supported nanoparticles, small(er) nanoclusters and single atoms have higher dispersion, are generally less active than their nanoparticle counterpart for the low-temperature oxidation reactions surveyed here [32,78]. A possible explanation is that on nanoparticles, a bimolecular Langmuir-Hinshelwood mechanism on the surface of nanoparticles may be paired with a Mars van Krevelen mechanism at the metal-support interface, whereas the latter mechanism dominates on single atoms as the binding sites are isolated from one another. A direct comparison between ceria-supported nanoparticles versus single atoms would shed light upon the difference and/or similarity in the mechanism of CO oxidation. The challenge of such comparative study is ensuring single atom catalysts contain only single atoms, while nanoparticle-based catalysts are void of single atoms. Confirmation of either outcome is challenging, in general, due to the lack of statistically relevant data that quantifies this type of data beyond a limited set of electron micrographs.

The competitive adsorption between $\mathrm{CO}$ and $\mathrm{H}_{2}$ is crucial in determining the selectivity in CO PROX reactions. According to relevant publications, $\mathrm{Pt}, \mathrm{Au}$ and $\mathrm{Cu}$ nanoparticles are promising candidates due to their stronger interaction with $\mathrm{CO}$ than $\mathrm{H}_{2}$. However, most of the studies evaluated the $\mathrm{CO}_{2}$ selectivity under relatively high $\mathrm{CO}$ concentrations $(\sim 1 \%)$ where saturated adsorption of $\mathrm{CO}$ on all metal sites is expected, whereas high $\mathrm{CO}_{2}$ selectivity at much lower $\mathrm{CO}$ concentrations $(<50 \mathrm{ppm})$ is required to meet practical requirements. Single-atom catalysts show great potential for PROX of $\mathrm{CO}$ in the presence of $\mathrm{H}_{2}$ due to their inability to dissociatively adsorb $\mathrm{H}_{2}$, and more studies understanding the mechanism of PROX on single-atom catalysts are anticipated. Single-atom catalysts show great potential for PROX of $\mathrm{CO}$ in the presence of $\mathrm{H}_{2}$ due to the nature of single sites and their inability to dissociatively adsorb $\mathrm{H}_{2}$, yet few studies have been reported on CO-PROX on such catalysts. More studies on the activity and $\mathrm{CO}_{2}$-selectivity of PROX on ceria-supported single-atom catalysts, the comparison to supported nanoparticles, and understanding of the mechanisms, are anticipated.

\section{References}

[1] H. S. Gandhi, A. G. Piken, M. Shelef, R. G. Delosh, SAE Tech. Pap., 1976, 760201.

[2] T. Montini, M. Melchionna, M. Monai, P. Fornasiero, Chem. Rev., 2016, 116, 5987-6041.

[3] E. Aneggi, M. Boaro, C. De Leitenburg, G. Dolcetti, A. Trovarelli, J. Alloys Compd., 2006, 408-412, 1096-1102.

[4] R. J. Gorte, AIChE J., 2010, 56, 1126-1135.

[5] A. Trovarelli, C. De Leitenburg, M. Boaro, G. Dolcetti, Catal. Today, 1999, 50, 353-367.

[6] L. Liu, A. Corma, Chem. Rev., 2018, 118, 4981-5079.

[7] L. R. Morss, Handbook on the Physics and Chemistry of Rare Earths; Elsevier: New York, 1994, Vol. 18.

[8] D. R. Mullins, Surf. Sci. Rep., 2015, 70, 42-85.

[9] G. J. VanHandel, R. N. Blumenthal, J. Electrochem. Soc., 1974, 121, 1198-1202.

[10] Z. Wu, M. Li, J. Howe, H. M. Meyer Iii, S. H. Overbury, Langmuir, 2010, 26, 16595-16606.

[11] P. Mars, D. W. Van Krevelen, Chem. Eng. Sci., 1954, 3, 41-59.

[12] R. Burch, Phys. Chem. Chem. Phys., 2006, 8, 5483-5500.

[13] F. Mariño, G. Baronetti, M. Laborde, N. Bion, A. Le Valant, F. Epron, D. Duprez, Int. J. Hydrogen Energy, 2008, 33, 1345-1353.

[14] M. Piumetti, T. Andana, S. Bensaid, N. Russo, D. Fino, R. Pirone, Nanoscale Res. Lett., 2016, 11, 1-8.

\section{Graphical Abstract}

Chin. J. Catal., 2020, 41: 951-962 doi: 10.1016/S1872-2067(20)63557-4

Influence of metal nuclearity and physicochemical properties of ceria on the oxidation of carbon monoxide

Linxi Wang, Shyam Deo, Kerry Dooley, Michael J. Janik*, Robert M. Rioux*

The Pennsylvania State University, USA; Louisiana State University, USA

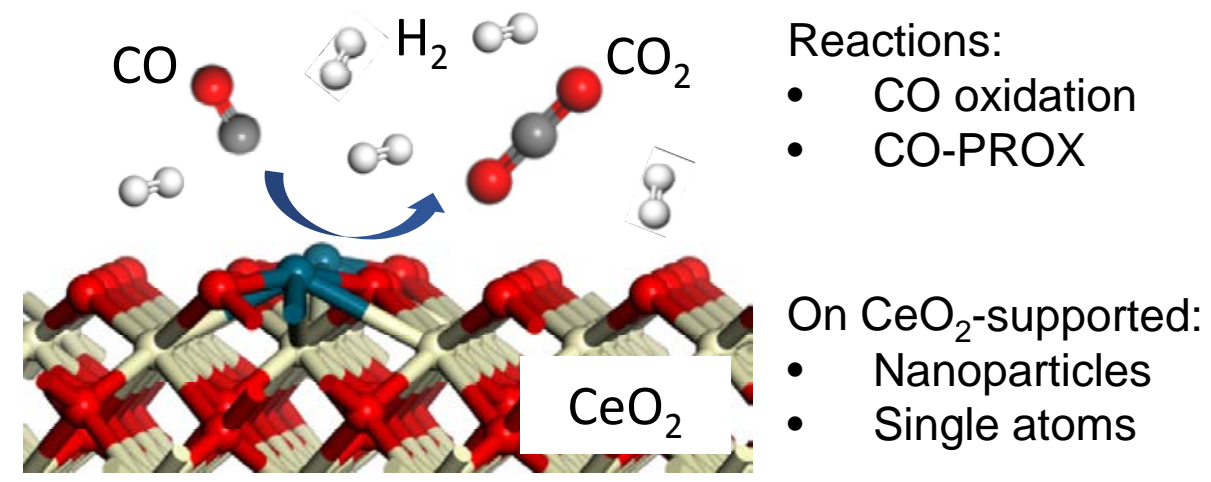

This paper reviews recently published work on the (preferential) oxidation of CO (in excess H2) on ceria-supported metal catalysts. The catalytic performance and reaction mechanism are compared among single atoms and nanoparticles of different metals. 
[15] T. Désaunay, G. Bonura, V. Chiodo, S. Freni, J. P. Couzinié, J. Bourgon, A. Ringuedé, F. Labat, C. Adamo, M. Cassir, J. Catal., 2013, 297, 193-201.

[16] A. Cao, R. Lu, G. Veser, Phys. Chem. Chem. Phys., 2010, 12, 13499-13510.

[17] J. Paier, C. Penschke, J. Sauer, Chem. Rev., 2013, 113, 3949-3985.

[18] A. Ruiz Puigdollers, P. Schlexer, S. Tosoni, G. Pacchioni, ACS Catal., 2017, 7, 6493-6513.

[19] D. B. Pal, R. Chand, S. N. Upadhyay, P. K. Mishra, Renew. Sustain. Energy Rev., 2018, 93, 549-565.

[20] J. Liu, ACS Catal., 2017, 7, 34-58.

[21] B. C. Gates, Trends Chem., 2019, 1, 99-110.

[22] B. Han, R. Lang, B. Qiao, A. Wang, T. Zhang, Chin. J. Catal., 2017, 38, 1498-1507.

[23] B. Hammer, J. K. Nerskov, Nature, 1995, 376, 238-240.

[24] M. A. Centeno, T. Ramírez Reina, S. Ivanova, O. H. Laguna, J. A. Odriozola, Catalysts, 2016, 6, 158/1-158/30.

[25] M. Han, X. Wang, Y. Shen, C. Tang, G. Li, R. L. Smith, J. Phys. Chem. C, 2010, 114, 793-798.

[26] J. Guzman, S. Carrettin, A. Corma, J. Am. Chem. Soc., 2005, 127, 3286-3287.

[27] S. Carrettin, P. Concepción, A. Corma, J. M. López Nieto, V. F. Puntes, Angew. Chemie Int. Ed., 2004, 43, 2538-2540.

[28] M. Boronat, A. Leyva-Perez, A. Corma, Acc. Chem. Res., 2014, 47, 834-844.

[29] J. A. von Bokhoven, J. T. D. Miller, J. Phys. Chem. C, 2007, 111, 9245-9249.

[30] A. Y. Klyushin, M. T. Greiner, X. Huang, T. Lunkenbein, X. Li, O. Timpe, M. Friedrich, M. Hävecker, A. Knop-Gericke, R. Schlögl, Acs Catal., 2016, 6, 3372-3380.

[31] S. Zhang, X.-S. Li, B. Chen, X. Zhu, C. Shi, A.-M. Zhu, ACS Catal., 2014, 4, 3481-3489.

[32] A. Tereshchenko, V. Polyakov, A. Guda, T. Lastovina, Y. Pimonova, A. Bulgakov, A. Tarasov, L. Kustov, V. Butova, A. Trigub, A. Soldatov, Catalysts, 2019, 9, 385.

[33] Y. Yang, K. M. Saoud, V. Abdelsayed, G. Glaspell, S. Deevi, M. S. El-Shall, Catal. Commun., 2006, 7, 281-284.

[34] Z. Hu, X. Liu, D. Meng, Y. Guo, Y. Guo, G. Lu, ACS Catal., 2016, 6, 2265-2279.

[35] H.-H. Liu, Y. Wang, A.-P. Jia, S.-Y. Wang, F. Luo, J.-Q. Lu, Appl. Surf. Sci., 2014, 314, 725-734.

[36] O. Pozdnyakova, D. Teschner, A. Wootsch, J. Kröhnert, B. Steinhauer, H. Sauer, L. Toth, F. C. Jentoft, A. Knop-Gericke, Z. Paál, R. Schloegl, J. Catal., 2006, 237, 1-16.

[37] P. Bera, A. Gayen, M. S. Hegde, N. P. Lalla, L. Spadaro, F. Frusteri, F. Arena, J. Phys. Chem. B, 2003, 107, 6122-6130.

[38] Y. Gao, W. Wang, S. Chang, W. Huang, ChemCatChem, 2013, 5, 3610-3620.

[39] C. S. Polster, R. Zhang, M. T. Cyb, J. T. Miller, C. D. Baertsch, J. Catal., 2010, 273, 50-58.

[40] M. Cargnello, V. V. T. Doan-Nguyen, T. R. Gordon, R. E. Diaz, E. A. Stach, R. J. Gorte, P. Fornasiero, C. B. Murray, Science, 2013, 341, 771-773.

[41] F. Morfin, T.-S. Nguyen, J.-L. Rousset, L. Piccolo, Appl. Catal. B, 2016, 197, 2-13.

[42] W. Song, E. J. M. Hensen, Catal. Sci. Technol., 2013, 3,3020-3029.

[43] Q. Fu, H. Saltsburg, M. Flytzani-Stephanopoulos, Science, 2003, 301, 935-938.

[44] H. Y. Kim, H. M. Lee, G. Henkelman, J. Am. Chem. Soc., 2012, 134, 1560-1570.

[45] H. Ha, S. Yoon, K. An, H. Y. Kim, ACS Catal., 2018, 8, 11491-11501.

[46] W. Song, Y. Su, E. J. M. Hensen, J. Phys. Chem. C, 2015, 119,
27505-27511.

[47] C. J. Zhang, P. Hu, J. Am. Chem. Soc., 2001, 123, 1166-1172.

[48] F. Mariño, C. Descorme, Duprez, D. Appl. Catal. B, 2004, 54, 59-66.

[49] O. Pozdnyakova, D. Teschner, A. Wootsch, J. Kröhnert, B. Steinhauer, H. Sauer, L. Toth, F. C. Jentoft, A. Knop-Gericke, Z. Paál, R. Schloegl, J. Catal., 2006, 237, 17-28.

[50] D. Teschner, A. Wootsch, O. Pozdnyakova-Tellinger, J. Kröhnert, E. M. Vass, M. Hävecker, S. Zafeiratos, P. Schnörch, P. C. Jentoft, A. Knop-Gericke, R. Schloegl, J. Catal., 2007, 249, 318-327.

[51] O. Pozdnyakova-Tellinger, D. Teschner, J. Kröhnert, F. C. Jentoft, A. Knop-Gericke, R. Schlögl, A. Wootsch, J. Phys. Chem. C, 2007, 111, 5426-5431.

[52] A. Luengnaruemitchai, S. Osuwan, E. Gulari, Int. J. Hydrogen Energy, 2004, 29, 429-435.

[53] F. Arena, P. Famulari, G. Trunfio, G. Bonura, F. Frusteri, L. Spadaro, Appl. Catal. B, 2006, 66, 81-91.

[54] S. Scirè, C. Crisafulli, P. M. Riccobene, G. Patanè, A. Pistone, Appl. Catal. A, 2012, 417-418, 66-75.

[55] W. Deng, J. De Jesus, H. Saltsburg, M. Flytzani-Stephanopoulos, Appl. Catal. A, 2005, 291, 126-135.

[56] M. Cargnello, C. Gentilini, T. Montini, E. Fonda, S. Mehraeen, M. Chi, M. Herrera-Collado, N. D. Browning, S. Polizzi, L. Pasquato, P. Fornasiero, Chem. Mater., 2010, 22, 4335-4345.

[57] G. Avgouropoulos, T. Ioannides, H. K. Matralis, J. Batista, S. Hocevar, Catal. Lett., 2001, 73, 33-40.

[58] J. da, S. L. Fonseca, H. S. Ferreira, N. Bion, L. Pirault-Roy, M. Do, M. do C. Rangel, D. Duprez, F. Epron, Catal. Today, 2012, 180, 34-41.

[59] N. Bion, E. Florence, M. Moreno, F. Marino, D. Duprez, Top. Catal., 2008, 51, 76-88.

[60] L.-C. Chung, C.-T. Yeh, Catal. Commun., 2008, 9, 670-674.

[61] C. R. Jung, J. Han, S. W. Nam, T.-H. Lim, S.-A. Hong, H.-I. Lee, Catal. Today, 2004, 93-95, 183-190.

[62] C. G. Maciel, T. de F. Silva, M. I. Hirooka, M. N. Belgacem, J. M. Assaf, Fuel, 2012, 97, 245-252.

[63] D. Gamarra, C. Belver, M. Ferná Ndez-García, A. Martínez-Arias, J. Am. Chem. Soc., 2007, 129, 12064-12065.

[64] A. Hornés, A. B. Hungría, P. Bera, A. Ló pez Cá mara, M. Ferná ndez-García, A. Martínez-Arias, L. Barrio, M. Estrella, G. Zhou, J. J. Fonseca, J. C. Hanson, J. A. Rodriguez, J. Am. Chem. Soc., 2010, 132, 34-35.

[65] X. Guo, R. Zhou, Catal. Sci. Technol., 2016, 6, 3862-3871.

[66] M. Monte, G. Munuera, D. Costa, J. C. Conesa, A. Martínez-Arias, Phys. Chem. Chem. Phys., 2015, 17, 29995-30004.

[67] Y. Xie, J. Wu, G. Jing, H. Zhang, S. Zeng, X. Tian, X. Zou, J. Wen, H. Su, C.-J. Zhong, P. Cui, Appl. Catal. B, 2018, 239, 665-676.

[68] M. Monte, D. Gamarra, A. López Cámara, S. B. Rasmussen, N. Gyorffy, Z. Schay, A. Martínez-Arias, J. C. Conesa, Catal. Today, 2014, 229, 104-113.

[69] G. Jing, L. Zhang, Y. Ma, J. Wu, Q. Wang, G. Wu, L. Yan, S. Zeng, CrystEngComm, 2019, 21, 363-371.

[70] B. Qiao, J. Liu, Y.-G. Wang, Q. Lin, X. Liu, A. Wang, J. Li, T. Zhang, J. Liu, ACS Catal., 2015, 5, 6249-6254.

[71] K. Ding, A. Gulec, A. M Johnson, N. M. Schweitzer, G. D. Stucky, L. D. Marks, P. C. Stair, Science, 2015, 350, 189-192.

[72] V. L. Zholobenko, G.-D. Lei, B. T. Carvill, B. A. Lerner, W. M. H. Sachtler, J. Chem. Soc. Faraday Trans., 1994, 90, 233-238.

[73] L. DeRita, S. Dai, K. Lopez-Zepeda, N. Pham, G. W. Graham, X. Pan, P. Christopher, J. Am. Chem. Soc., 2017, 139, 14150-14165.

[74] J. Li, Y. Tang, Y. Ma, Z. Zhang, F. Tao, Y. Qu, ACS Appl. Mater. Interfaces, 2018, 10, 38140.

[75] C. Wang, X.-K. Gu, H. Yan, Y. Lin, J. Li, D. Liu, W.-X. Li, J. Lu, ACS Catal., 2017, 7, 887-891. 
[76] L. Nie, D. Mei, H. Xiong, B. Peng, Z. Ren, X. I. Pereira Hernandez, A. De la Riva, M. Wang, M. H. Engelhard, L. Kovarik, A. K. Datye, Y. Wang, Science, 2017, 358, 1419-1423.

[77] H. Wang, J. Shen, J. Huang, T. Xu, J. Zhu, Y. Zhu, C. Li, Nanoscale, 2017, 9, 16817-16825.

[78] G. Spezzati, Y. Su, J. P. Hofmann, A. D. Benavidez, A. T. DeLaRiva, J. McCabe, A. K. Datye, E. J. M. Hensen, ACS Catal., 2017, 7, 6887-6891.

[79] G. Spezzati, A. D. Benavidez, A. T. DeLaRiva, Y. Su, J. P. Hofmann, S. Asahina, E. J. Olivier, J. H. Neethling, J. T. Miller, A. K. Datye, E. J. M.
Hensen, Appl. Catal. B, 2019, 243, 36-46.

[80] Y.-Q. Su, I. A. W. Filot, J.-X. Liu, E. J. M. Hensen, ACS Catal., 2018, 8, 75-80.

[81] W. Song, E. J. M. Hensen, J. Phys. Chem. C, 2013, 117, 7721-7726.

[82] M. Farnesi Camellone, S. Fabris, J. Am. Chem. Soc., 2009, 131, 10473-10483.

[83] J.-C. Liu, Y.-G. Wang, J. Li, J. Am. Chem. Soc., 2017, 139, 6190-6199.

[84] Y. G. Wang, D. Mei, V. A. Glezakou, J. Li, R. Rousseau, Nat. Commun., 2015, 6, 6511 .

\title{
金属核及氧化铈的物理化学性质对一氧化碳氧化的影响
}

\author{
Linxi Wang ${ }^{\text {a }}$, Shyam Deo ${ }^{\text {a }}$, Kerry Dooley ${ }^{c}$, Michael J. Janik ${ }^{\mathrm{a}, *}$, Robert M. Rioux ${ }^{\mathrm{a}, \mathrm{b}, \#}$ \\ a宾夕法尼亚州立大学化工系, 大学园, PA 16801, 美国

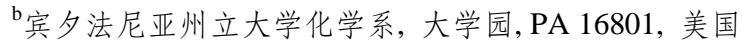 \\ ‘路易斯安那州立大学化工系, 巴顿鲁日, LA 70803, 美国
}

\begin{abstract}
摘要: 氧化铈独特的氧化还原性能使其适合用作氧化反应中的催化剂或载体. 氧化铈负载的过渡金属纳米粒子或孤立的 单原子提供了金属-载体界面, 从而降低了去除界面氧原子的能耗, 提供了可以参与Man Van Kulvian氧化过程的活性氧物 种. $\mathrm{CO}$ 氧化是测试氧化铈负载催化剂还原性的主要探针反应, 并且它常见于在相对低温下消除 $\mathrm{CO}$ 的各种应用中. 在过量 $\mathrm{H}_{2}$ 中优先氧化 $\mathrm{CO}(\mathrm{PROX})$ 反应可控制 $\mathrm{CO}$ 浓度达到超低水平, 以防止氢氧化电催化剂中毒. 催化剂在 $\mathrm{CO}$ 氧化反应中的活性 和在PROX反应中对 $\mathrm{CO}$ 和 $\mathrm{H}_{2}$ 的选择性取决于金属物种的种类和分散性、 $\mathrm{CeO}_{2}$ 的结构和化学性质以及催化剂的合成方法. 在这篇综述中, 我们总结了最近发表的关于 $\mathrm{CeO}_{2}$ 负载的金属纳米粒子和单原子催化CO氧化和PROX反应的相关工作; 以 及不同的负载金属和同种金属在普通 $\mathrm{CeO}_{2}$ 表面上的反应性. 我们还总结了密度泛函理论计算中提出的最可能的反应机理; 并且讨论了各种负载型金属在PROX反应中影响 $\mathrm{CO}$ 氧化选择性的因素.
\end{abstract}

关键词: 氧化铈; $\mathrm{CO}$ 氧化; 金属纳米粒子; 单原子; PROX

收稿日期: 2019-11-05. 接受日期: 2019-12-02. 出版日期: 2020-06-05.

*通讯联系人. 电子信箱: mjj13@psu.edu

\#通讯联系人. 电子信箱: rmr189@psu.edu

本文的电子版全文由Elsevier出版社在ScienceDirect上出版(http://www.sciencedirect.com/science/journal/18722067). 